\title{
Krapp’s Last Tape in Great Britain: Production History amid Changing Practice
}

\section{Andrew Head}

As a mainstay of Beckett's dramatic canon, productions of Krapp's Last Tape occupy an enduring position in the history of post-war British theatre. Written during the flowering of new English playwriting centred on the Royal Court Theatre and emerging as one of Beckett's major theatrical successes of the $1950 \mathrm{~s}$, the play continues to resonate and is often programmed as part of live events. Whether as part of planned repertory seasons in metropolitan or regional theatres; as part of an ever-burgeoning national festival culture; or when presented on alternative media platforms such as film or television, the play lends itself to differing cultural gatherings that are often quite removed from its theatrical origins. The varied and diverse contexts within which Beckett's relatively short work for the stage has been performed since its genesis speak as much about the logistical and practical expediencies afforded by the text as they do of the play's richly lyrical and wistfully autobiographical content. In addition to the play's extended monologue of regret for an ultimately unfulfilled life, the work offers much in terms of its portability in production and the potential it has for presentation in a wide range of venues and performance contexts. This has led to its life in performance being framed in ways that have shifted according to venue and audience. The play can be regarded simultaneously as both a product of twentieth-century avant-garde performance practice - in which its position within Beckett's oeuvre cements its status as a significant work in the wider context of twentieth-century drama - as well as an example of innovative civic arts provision for local and provincial audiences. At a time when the Arts Council of Great Britain (in its various manifestations since the Second World War) sought to democratize theatregoing and, in doing so, to wrest the instrumental benefits of the capital's rich cultural experiences away from the metropolitan centres, early performances of this play 
provided directors and programmers with a conveniently scaled work that could be offered and framed for their audiences in a variety of ways that, for many, might have constituted a first introduction to the contemporary avant-garde.

Since Beckett's death, more recent productions have seen a shift of focus from the centrality of the writing (including an emphasis on its mournful lyricism as well as its reflective study of the nature of memory) and the starkly economical stage pictures offered in the text, towards an emphasis on performance and the challenges that the work poses for the actor playing Krapp. However, throughout its production history, the play's position either as low-key, provincial production or high-profile, metropolitan event has tended to operate this distinction in parallel, sometimes simultaneously. The present chapter is as much concerned with the ways in which productions of the play have operated in the former context - in which the localized needs of provincial theatre institutions and their audiences have impacted on the production and reception of the play - as it is with the latter's emphasis on the play's performance in major cultural centres. From its presentation as something of an avant-garde curiosity in the wake of Beckett's award of the Nobel Prize in 1969, to an increasing emphasis on its canonical status as the decades wore on, critical reception of the play has moved from early considered attempts at interpretation to later appraisals of various actors' perceived abilities at tackling what has been seen by some as a growing challenge that increases in proportion to the text's enlarging iconography.

Examples of this duality in production and performance - between the provincial and the metropolitan or the poetry of the text and the challenge for the actor - are numerous. In performance, the work is usually between 50-60 minutes in duration and this alone has entailed a flexible approach to programming whereby directors and artistic directors have been able to insert productions in diverse and differing time slots. Lunchtime and daytime slots as part of festival programmes have been a feature of the play's numerous presentations. 
Although its production history shows a marked reluctance on the part of Beckett himself (or the Beckett Estate since his death) to programme the work alongside works by other authors in repertory contexts, ${ }^{1}$ this has not prevented companies and theatre institutions from staging the work in novel ways. In the Autumn of 1969, the Sheffield Playhouse staged the play as part of a season of lunchtime performances. Advance publicity for these events promoted the opportunity as 'an initial experiment as part of a general move to make greater use of the theatre. [...] Bring your own sandwiches and in the space of the office dinner hour you can have an extra taste of Orton, Pinter or Beatle John Lennon' (The Sheffield Star, September 1969). In review, critics acclaimed the idea with generally very good audiences in attendance and the varied fare provoking positive responses: 'The previous three plays - by Pinter, Beckett and Lennon - all run on pretty bizarre lines. [...] The brief break at the Playhouse could have a disturbing effect on productivity rates in the city $[\ldots]$ the theatre has been packed for each performance.' (The Sheffield Star, October 1969) However, production opportunities notwithstanding, it is the content of Beckett's work that endures in terms of imagery and its thematic concerns. Before considering the play's production history further, beyond the 1960s and in terms of its increasing status as part of the wider theatrical canon, it is important to consider some of the internal textual issues related to the work that impact on production.

Beckett's solo piece for a male actor was written in the early part of 1958. It is noteworthy for several reasons when viewed in the full context of his dramatic output. The play was written and first performed some five years after his first theatrical success with Waiting for Godot (1953). Subsequent to this major career breakthrough, Beckett followed up this success with Endgame (1957) and the short mime piece, Act Without Words, in the same year. Although both of these shorter plays display a theatrical complexity in their respective approaches, implied or otherwise, to the paradoxes of language and existence, both are replete 
with a similar attitude to physicality and a sometimes overtly presentational approach required of actors, as found in key passages from the earlier Waiting for Godot. It is this emphasis on a presentational approach to characterization, one in which Beckett's acknowledged debt to the variety theatre or early silent cinema is made flesh in his rendering of character, that acquires greater complexity in Krapp's Last Tape. One of the significant features of the play is the extent to which the performance of the text requires the actor to 'turn in' on himself visibly, and almost literally, in order to communicate some of the key moments in the text. It is this point of inward reflection, and the way it balances with a simultaneous outward projection, that often defines the approach taken by both actor and director. As explored later in this chapter, this role is also representative of an emerging approach to performance, and by extension, the practice of acting in Beckett's early style. During Beckett's career in the theatre, it is an approach which also can be seen to develop over time as his varying experiences across media, with changing collaborators, and in response to the development of his writing, entail revisions of approach as he returns to mount revived productions that would go on to define his later style in the theatre. For example, in Beckett's 1977 production of Krapp's Last Tape with Rick Cluchey in the role, Beckett's injunction that the part be played with a close attention to the musical qualities of the verbal and visual dimensions of the text indicate a growing need to turn away from psychological portrayal and veer towards formalist image-making. ${ }^{2}$ This move towards abstraction is characterized by his demand that Cluchey 'bring rhythm into every detail' and that movements and gestures 'be brought closer to the marionette ideal' (Herren 2002: 162). Graley Herren argues that it was Beckett's experiences working in television, specifically on Ghost Trio (1975), that enabled him to make the kind of changes that would not have been conceived at the time of the play's first production in the late $1950 \mathrm{~s}$. 
Patrick Magee was the first actor to perform the role in the play's original production at London's Royal Court Theatre in October 1958. He subsequently reprised the role for a BBC televised performance that was screened in November 1972. Of all the documented performances of this piece, this perhaps remains closest to its theatrical original in terms of the style of delivery. Magee adopts a staged, bordering on mannered, delivery in which the rasping, forceful tone of his voice contrasts with the frailty of his physical disposition. He chooses to gaze away from the desk towards the middle distance whilst cupping his ear in such a way that is faithful to the original stage direction:

He raises his head, broods, bends over machine, switches on and assumes listening posture, i.e. leaning forward, elbows on table, hand cupping ear towards machine, face front. (Beckett 2006: 217)

His is a poignancy that enables the audience to contrast the overt strength of the younger Krapp depicted on the tapes with the declining faculties of old age. Additionally, he is able to realize a listening posture that, by the end of the play, achieves a level of intimacy that befits his soulful reflection on the girl in the punt. In a letter to Alan Schneider in November 1958, Beckett reflected on Magee's performance in the original production at the Royal Court:

The most interesting discovery was the kind of personal relationship that developed between Krapp and the machine. [...] At the very end, when "I lay down across her etc." comes for the third time, the head goes down on the table and remains down until "Here I end etc." [...]. At this point too he has his arm round the machine. (Harmon 1998: 50) 
One of the challenges for the actor comes with the way in which the play is structured. Beckett had become intrigued by the possibilities of the new medium of magnetic tape on a visit to the BBC in January 1958 when reviewing some recordings of his prose work that had been broadcast earlier in the previous year (Knowlson 1996: 444). He was fascinated by the potential that now existed for the human voice to be easily recorded and played back almost instantaneously. In Krapp's Last Tape, we see Beckett exploring the possibilities for the selection and juxtaposition of fragments of human memory, as this frenetically punctuated stage direction illustrates:

Long Pause. He suddenly bends over machine, switches off, wrenches off tape, throws it away, puts on the other, winds it forward to the passage he wants, switches on, listens staring front. (Beckett 2006: 223)

Here, not only is it possible to observe the physicalization of this act of selection and juxtaposition. We also witness the kind of tactile engagement between man and technology that would not only stand out in productions of the play but which would also go on to become a feature of contemporary performance practice in the ensuing decades. Writing in the context of postmodern articulations of performance in the mid 1990s, Elinor Fuchs focuses on the theatricalized, inanimate object as symptomatic of a 'theatre of things'; a phenomenon used as a means of defining the progressive retreat from traditional notions of character and representation throughout the twentieth century. She argues that the insecurities and instabilities of character on the postmodern stage are perhaps substituted by the certainties of the inanimate object (Fuchs 1996). In addition to this 'theatre of things', a theatre of doing has also emerged as part of a tendency within contemporary performance practice that is born out 
of this retreat from character and which possibly accounts for the play's enduring ability to resonate in production across the decades.

As the production history of the play progresses, so does the nature of contemporary avant-garde performance. Perhaps prompted by Alain Robbe-Grillet's assertion that the tramps in Waiting for Godot are 'irremediably present' (Robbe-Grillet 1965: 111), the question of embodied agency and the ways in which Beckett's characters use their presence on stage has preoccupied artists and practitioners since the early theatrical successes of the $1950 \mathrm{~s}$. It is a preoccupation that has tended towards the exploitation of an essential paradox of the actor - the tension that exists between physical presence and literary invisibility - and which resonates strongly enough in Beckett's early drama so as to provide a stimulus for future generations. Krapp's presence, mediated through the actor cast in the role, is one that uses the concrete realities of objects and their immutable form as a means of occupying space and time. This is most acutely on display in the earlier stages of the play. In busying himself with the paraphernalia of Krapp's besieged domesticity, the actor lends a heightened theatricality to otherwise mundane tasks: examining his pocket watch, a spool of tape, an old envelope; consuming bananas; loading a spool on to the tape recorder. In this sense, the chronic nature of the human condition suggested by Robbe-Grillet is axiomatic for Krapp. What is made available to the spectator is a sustained portrayal of the ways in which this man has chosen to occupy, to this point, his time. This study of the intersection between the quotidian in human agency and the performative realms of space, time and the exploitation of self is a feature of later performance practices that emerge within a postmodern tradition of performance making after this point. In this early example, not just of Beckett's dramatic writing, but of the gradual drift towards postmodernity, we can see these phenomena prefigured. Krapp's engagement with the tape recorder is seen as a tactile, almost visceral relationship of convenience in which the functional qualities of the machinery are subsumed within the physical interaction it 
requires. Beckett suggests that the relationship may go even further than the purely functional. In addition to the Schneider correspondence at the time of the play's premiere (cited above), his notes for the 1969 Berlin Schiller Theater production comment on an identifiably emotional, as well as functional, relationship with the tape recorder. Krapp's habitual documentation of his life can be seen as indicative of a 'tendency of a solitary person to enjoy affective relationships with objects, in particular here with tape-recorder. Smiles, looks, reproaches, caresses, taps, exclamations' (Knowlson 1992: 205). In the same volume, Beckett also identifies in his production notes 'at least 5 places where you can express [...] this relationship' (ibid: 245). Pierre Chabert, when directing this play (as La dernière bande) in Paris during 1975, describes the kind of engagement required of the actor: 'It is a law of Beckett's theatre (the dramatization of physical effort) that we find at several levels in Krapp's Last Tape: the effort to hear, to see, to get started, to bring back memory. The tension instead of lying in a clash between personalities, as in conventional drama, takes place inside the body of the character himself.' (Quoted in McMillan \& Fehsenfeld 1988: 292)

More recent productions have veered towards a more naturalistic portrayal with notable versions having been recorded for film following on from, or prior to, successful theatrical productions. ${ }^{3}$ Despite Beckett's general reluctance to agree to the transfer of his work between media during his lifetime, this play can be seen as an exception (in his lifetime he sanctioned Radio, TV and gramophone recordings of the work). For that reason, it is perhaps no accident that subsequent productions have adopted more filmic acting performances as the reservoir of available reference material has proliferated. Both Harold Pinter (2006) and Michael Gambon (2010) employed a comparatively internalized, inward portrayal of Krapp in which the complexities of Krapp's emotional state are expressed through a sometimes painful subtlety that reduces the poignancy of his situation to a series of hard-edged visual images. In performance this approach is grounded in gestural stillness as well as symbolic action. In 
review, Gambon's performance is seen by Charles Spencer to channel this complexity into Krapp's relationship with the tape recorder: 'As he listens again to his account of that last meeting with his lover, Gambon cradles the tape recorder in his arms, as if it were the body of his long-lost lover.' (Spencer 2010) Writing in The Guardian, Lyn Gardner focuses on Gambon's stasis: 'And then he sits immobile, as if welcoming the inevitable, smothering darkness. Only his eyes catch the light, two pinprick stars in a universe entirely without consolation.' (Gardner 2010) Gambon's performance can be held up as a useful example of the fine balance that exists between the varied approaches taken towards this role. The inward, reflective register acquired could easily have tipped over into a more overtly theatrical style. It is his ability to practice an economical, bordering on minimalistic style, that sets this performance, and others, apart from an approach that consciously seeks to explore the more expansive aspects of the character.

This expansive style can be seen in those earlier productions involving the more stylized renderings of Magee, and also Rick Cluchey. Video recordings of his 1977 performance reveal that Cluchey adopted a reverential, almost supplicatory stance towards the tape recorder as the prime means of access to the distant memories that Krapp finds it increasingly difficult to recall. The most thoroughly documented accounts of those who have performed the role since its premiere reveal that actors have tended towards one of two directions: a broadly representational style in which the implied reality of the character's situation is allowed to influence an internalized, almost haunted rendering, contrasted with a presentational approach in which theatricality and the externalized virtuosity of the actor's abilities is foregrounded for the spectator. An example of this virtuosity can be found in John Hurt's performance (2001, reprised in 2011) in which his playful approach during the opening banana sequence was described by one American reviewer as 'a clownish fillip of his own 
here, as Krapp playfully moves in and out of the square of bright light dividing him from the surrounding darkness' (Isherwood 2011).

Beckett is clear with regard to the extent to which the actor's relationship with the tape recorder should be based on emotion. He is clear in his stage directions at the beginning of the play that the action takes place in 'the future' and that Krapp has had the opportunity to record numerous entries, presumably using this tape recorder or one very similar. Aside from the content of the taped entries, there is a tangible sense of childlike fascination with the machine. The posture adopted when in the listening position is almost one of a penitent sinner or remorseful supplicant at the mercy of their past experiences. In the same way as the eponymous characters in medieval morality plays are forced to account for their actions in order to gain access to paradise, Beckett's Manichaean hero is forced to face the consequences of a life that has consciously turned away from the darkness of material, earthly preoccupations towards the light of spirituality in search of a similar fate. His act of worship at this twentieth century altar is therefore imbued with a complex web of emotional torment and attempted reconciliation that requires careful playing both in terms of the actor's posture as well as facial expression. Beckett was keen to highlight the importance of this in various items of correspondence. In a letter to Magee in March 1958, prior to the play's London premiere in October of that year, Beckett wrote: 'Krapp's face as he listens is of course three quarters of that battle. I made no attempt to indicate its changes and unchangingess, feeling that these could safely be left with you.' (Beckett 2014: 120) Early in the following month he wrote to George Devine, the director of the English Stage Company at the Royal Court, with a similar, if less quantifiably emphatic, statement: 'I made no attempt to describe Krapp's face as he listens, though this is a good half of the battle. [...] Expressiveness in blankness sums it up, I think, if that means anything.' (Ibid., 124) 
In describing his own attempt to realise these somewhat opaque directives from a writer still coming to terms with the play's potential, Chabert talks of the physical manifestations of this relationship between man and machine in rehearsal and performance: 'The look, the touching, the physical posture: moving from and returning to the machine. The changing expressions are important; they are reproachful, interrogative, defiant, excited [...] at other times they are expressions of complicity, love, good humour, as when Krapp laughs with his recorded voice.' (Quoted in McMillan \& Fehsenfeld 1989: 294) It is also the musicality of the text that presents challenges for the actor in this role. As a consistently deployed aspect of the Beckettian approach to acting, Krapp's Last Tape, at this relatively early stage of Beckett's writing for the stage, provides a working set of analogies for the actor that become more pronounced as the material develops during the remainder of his career. In the 1975 production, Chabert's notes reveal this emphasis on musicality having been broken down to three discreet elements: the text as score; the alternations between the two voices; and the relationship between the recorded voice and physical movement. Bringing these three elements together results in the completion of an overall final score when staged. A fourth element: that of the visual score, is also identified.

Once the basic structure identified by Chabert is established, the task of the director when working with an actor is to identify discrete points of alternation between the two voices as well as their transition from one to another and how they might be distinguished musically rather than naturalistically. This dialogue, or literary duet between the two identifiable voices in the play can be articulated differently according to the actor playing the role and the priorities of the director concerned. Musically, and tonally, the delivery of the text benefits from a contrast that can be recognized as striking both in its sense of sonic difference as well as its poignant associations. Actors appear to relish the optimization of this effect. The university academic and actor, Michael Patterson, has toured his own production of the play 
across a lengthy period since the early 1970s. When witnessed in the early 2000 s, the gap in time between the taped diary entries and the moment of performance was almost the same as stated in the text (Patterson was 34 when he recorded his tapes in the 1970s contrasting with Krapp's explicitly stated age of 39 in the published text. By the early 2000s the performance of the play occurred more or less 30 years later). This level of authenticity created marked differences in the vocal and consequently musical qualities of Patterson's voices. The strong, higher-pitched tone of his younger self contrasted starkly with the deeper and thinner resonances of the live performer.

The distinction between the quasi-naturalistic dialogue of the earlier plays that precede Krapp's Last Tape and the heightened lyricism and denaturalized, distanced interplay that exists between the two voices heard in the play, marks an important shift in Beckett's approach to dramatic writing. The actor playing Krapp has increased license to increase the gap between a psychologically determined, naturalistic performance register and its alternative: a formal, patterned, structured approach to delivery that is closer to music. Consequently, the play's production history reveals a range of performances that, depending on venue and context as well as the nature of the actors or the ethos of the company concerned, result in differing articulations of this distinction of approach - between the more conservatively representational, bordering on naturalistic, portrayals found mainly in the metropolitan centres, and the playfully experimental, quasi-musical delivery of the provincial underground. With regard to the latter, the critical record often describes some of these early productions as working with 'considerable ingenuity in making the duller stretches palatable' (South Wales Argus, 1969).

It is perhaps this emphasis on a playful approach to delivery or the possibilities of musical experimentation that have led to a number of student or youth theatre productions that have been performed either at large-scale festival environments such as the Edinburgh Fringe 
(for example, The Swansea University Players at Edinburgh's YMCA Theatre in 1969) or Youth Theatre events such as the Young People's Festival at the Soho Theatre, London in the summer of 1970. Age differentials notwithstanding, critical reception of these productions has often been positive: 'Mr Alexander's performance was shambling, blinking, lost in age and memory and, for all the inanity of it, very real' (The Stage, 1970). Somehow, in connecting audiences with the spirit of experimental theatre, fringe events such as these maintain an appetite for challenging drama for which there is a perceived hunger outside of the capital. One critic remarks as follows when reviewing John Warner as Krapp at the Thorndike Theatre, Leatherhead, in 1971: 'There is a need for more experimental drama - it is this type of play that keeps the theatre alive and evolving - and there are the audiences for it' (Surrey Advertiser, 1971).

Punctuating this cultural undercurrent of provincial, festival and youth theatre productions that connect local audiences to an articulation of avant-garde or experimental performance in the first decade after the play's premiere, is a series of key productions that emerge in the cultural centres of the UK that might be described as high profile in terms of their casting of a culturally significant actor. 'Significance', in this regard, might relate either to the actor's connection with Beckett during Beckett's period of theatrical activity or in terms of their perceived status in the cultural hierarchy of acting talent available at the time. Many of these actors also emerge from unexpected quarters that perhaps reflect Beckett's authorial debt to forms of performance that owe more to popular entertainment and early cinema than the contemporary avant-garde. In 1975, Max Wall performed the role under the direction of Magee at London's Greenwich Theatre. John Elsom, writing in 1983, described this performance as 'the finest performance in Britain of that bleak biography' (Elsom 1983: 265). It is no accident that Wall's comic-grotesque, balletic approach to a presentational style is brought to bear on the character of Krapp at this still relatively early stage in the play's 
production history. Under Magee's direction, his talents as a physical performer with a playful tendency to experiment with the musical limits of language, ${ }^{4}$ can be seen to fit well with an early disposition towards the presentation of Krapp as a decrepit clown. Wall would reprise the role in 1986 at London's Riverside Studios.

Later productions have veered more towards realism, in which the outwardly manifested physical signs of old age and infirmity are of equal importance compared to the lyrical poignancy of the recordings or the slapstick of the opening comic routines. The playful and experimental clowning of the early productions giving way to a gritty, more pessimistic naturalism that is sometimes reflective of the personal circumstances of the actor concerned. David Warrilow, one of Beckett's most important actors, performed the role in 1990 at the Haymarket Theatre, Leicester followed by the Riverside Studios, London. A review for The Observer at the time describes his overall performance with an emphasis on its aged physicality: 'Warrilow is performing Krapp's Last Tape with a sepulchral croak and a devastating sense of wonderment and loss' (Coveney 1990: 41). Warrilow's performance clearly aims to provide a distinction between the light and shade of vocal patterning found in the two voices represented: 'both the rich and glowing voice of the young man on tape, the harsh bark of the old man seated at the table' (Leicester Mercury, 1989). Pinter's more recent performance, in 2006, was greeted by The Guardian's theatre critic, Michael Billington, as 'the harshest, least sentimental reading of Beckett's play I can recall. [...] Pinter sits behind a desk in a motorised wheelchair. The dominant impression is of total entrapment' (2006).

The performance history of this play can therefore be seen as a developmental progression that echoes the patterning of light and shade found in the play text. In addition to the frailties of age found in both the central character as well as the actor playing Krapp, productions of the play can also be seen to operate within a strict ecosystem wherein the onstage aesthetics of performance sometimes rub against an off-stage world in which the 
economics of arts provision can be uncomfortably located in close proximity. At the Lakeside Arts Centre in Nottingham during 2003, a 'Krapp's Last Supper' was offered to theatregoers keen to include a night at the theatre as part of a romantic Valentine's night treat. This was an experience that supplied dinner, the show and a signed programme; a package that could be purchased, at a favourable rate, during the week of the 14 February. This work is not immune from the changing funding arrangements of provincial British arts organizations and the status of this work as cultural capital - a commodity to be exploited for the economic survival of local and regional institutions - and this is a common theme that operates throughout the last three decades.

Ultimately, perhaps it is the actor playing Krapp who is most instrumental in shaping a performance history of this work that, in keeping with the many textual revisions that took place during Beckett's own theatrical interventions, has reflected the changing perceptions of audiences and those directors arriving at the work with fresh understandings of how the material might resonate within a contemporary cultural climate. Whether the actor is performing in the context of small-scale, low profile productions as part of a festival or provincial environment; or as an established, iconic presence within the theatrical landscape, the role increasingly makes demands of the actor that reflect the growing significance of the work as part of the British theatrical repertoire. It is a work that also reflects our changing abilities to process memory. As we progress through an age in which recording technology, and the social media it facilitates, becomes increasingly embedded in our subjective experiences of contemporary culture, the tape machine - cumbersome and awkward in its materiality - diminishes in appearance and visibility as the decades wear on. As the technological means by which Krapp is able to record his recollections gradually disappears from view, and authentic renderings of the text in performance become increasingly difficult, 
what is left is a production record in which the embodiment of the character provides the enduring collective memory. 


\section{Bibliography}

Beckett, S. (2006), Samuel Beckett: The Complete Dramatic Works, London: Faber \& Faber.

Beckett, S. (2014), The Letters of Samuel Beckett. Volume 3. 1957-1965, G. Craig, M. Fehsenfeld, D. Gunn \& L. Overbeck, eds., Cambridge: Cambridge University Press. Billington, M. (2006), 'Krapp’s Last Tape’, The Guardian, 16 October. Available online: www.theguardian.com/stage/2006/oct/16/theatre.beckettat100 (accessed 1 April 2015).

Coveney, M. (1990), 'Sometimes the jokes have to be Irish', The Observer, 14 January: 41.

Elsom, J. (1983), 'Samuel Beckett, Max Wall and Me', Contemporary Theatre Review, 242 (May): 261-65.

Fuchs, E. (1996), The Death of Character: Perspectives on Theater After Modernism, Indiana: Indiana University Press.

Gardner, L. (2010), 'Krapp’s Last Tape, Duchess, London', The Guardian, 23 September. Available online: www.theguardian.com/stage/2010/sep/23/krapps-last-tapelyn-gardner (accessed: 25 June 2015).

Harmon, M. ed. (1998), No Author Better Served: the Correspondence of Samuel Beckett \& Alan Schneider, Cambridge, Mass.: Harvard University Press.

Herren, G. (2002), 'Ghost Duet, or Krapp's First Videotape', in A. Moorjani \& C. Veit (eds), Samuel Beckett: Endlessness in the Year 2000, 159-166, Amsterdam: Rodopi Press.

Hull Truck Theatre (2012), Spoonface Steinberg/Krapp’s Last Tape: Education Pack.

Isherwood, C. (2011), 'Unspooling Memories from the Soul on a Machine', The New York Times, 8 December.

Available online: www.nytimes.com/2011/12/09/theater/reviews/krapps-lasttape-with-john-hurt-at-bam-review.html?_r=0 (accessed: 25 June 2015).

Knowlson, J. ed., (1992), The Theatrical Notebooks of Samuel Beckett, Volume 3: Krapp's 
Last Tape, London: Faber \& Faber.

Knowlson, J. (1996), Damned to Fame: the Life of Samuel Beckett, London: Bloomsbury.

Leicester Mercury (1989), Untitled article, 12 October, held at the University of Reading's Samuel Beckett Collection (KRA-1989).

McMillan, D. \& Fehsenfeld, M. (1988), Beckett in the Theatre: the Author as Practical Playwright and Director, London: John Calder.

Robbe-Grillet, A. (1963), For a New Novel, Evanston, Illinois: Northwestern University Press.

Sheffield Star (1969), Untitled article, 24 September, held at the University of Reading's Samuel Beckett Collection (KRA-1969/MS 1792 f.622).

Sheffield Star (1969), Untitled article, 31 October, held at the University of Reading's Samuel Beckett Collection (KRA-1969/MS 1792 f.622).

Spencer, C. (2010), 'Krapp’s Last Tape, Duchess Theatre, review', The Daily Telegraph, 23 September. Available online: www.telegraph.co.uk/culture/theatre/8020032/Krapps-Last-Tape-DuchessTheatre-review.html (accessed 25 June 2015).

The Stage (1970), Untitled article, 2 July, held at the University of Reading's Samuel Beckett Collection (KRA-1970).

Surrey Advertiser (1971), Untitled article, 21 May, held at the University of Reading's Samuel Beckett Collection (KRA-1971). 


\section{Notes}

${ }^{1}$ More recent productions of the play have celebrated their success in circumventing this perceived constraint. For example, Hull Truck Theatre's production in 2012 (as part of a double-bill presented with Lee Hall's Spoonface Steinberg) used the following in its Education Pack released to the media: 'The production marks the first time plays by Lee Hall (Billy Elliott) and Samuel Beckett (Waiting for Godot) will have been performed together as a double-bill. Previously, the Beckett Estate has only allowed the work of Harold Pinter to be performed in this way.' (Hull Truck Theatre 2012)

${ }^{2}$ Cluchey's performance was with the San Quentin Drama Workshop and was eventually performed in the UK during 1980, where Beckett directed some rehearsals of the piece (along with Endgame) at the Riverside Studios in London. It was performed at the Young Vic and the Arts Theatre during July and August of that year prior to a transfer to Dublin.

${ }^{3}$ Most notably, John Hurt performed the role in 2001 for the Beckett on Film project directed by Atom Egoyan. He reprised the role for the theatre in 2011 (using the audio tapes from the 2001 production). Harold Pinter was cast in the role for a Royal Court production directed by Ian Rickson in 2006 in order to mark the theatre's $50^{\text {th }}$ anniversary. The production was reproduced as a film for DVD release in 2007 and broadcast on BBC4 in 2009.

${ }^{4}$ John Elsom, in the same article - an account of his meeting with Max Wall in the 1970s also draws attention to similarities between Beckett's and Wall's fondness for arbitrary language play: “"Spoo-oo-1l” And who used that word with langorous derision? Beckett. “Stoo-oo-1l” And who massacred that term with a melancholy affection? Wall.' (Elsom 1983: 264) 